\title{
Pengaruh Nyanyian Karya A. B. Simpson dalam Pelayanannya Dan Relevansinya Bagi Gereja Kemah Injil Indonesia
}

\author{
Bernabas Anderias Laabui
}

\begin{abstract}
Abstrak
Tujuan penulisan skripsi ini adalah: Pertama, Nyanyian Kemenangan Iman berguna untuk mengubah hidup pribadi seseorang untuk dapat menjadi lebih baik dari kehidupan yang lama kepada kehidupan yang baru atau lahir baru. Kedua, Nyanyian Kemenangan Iman berguna untuk dapat menyadarkan umat dari setiap kesalahan yang telah dilakukan. Ketiga, Nyanyian Kemenangan Iman berguna untuk menguatkan umatnya dalam menghadapi persoalan dan masalah hidup saat ini yang semakin hari semakin jahat. Keempat, syair dari Nyanyian Kemenangan Iman memiliki makna dan tujuan yang sangat mendalam dan mempengaruhi kehidupan setiap pribadi. Kelima, Nyanyian sebagai sala satu sarana yang digunakan A.B. Simpson dalam menyampaikan firman Tuhan kepada orang-orang yang belum mengenal Tuhan.
\end{abstract}

Kata-kata Kunci : Pengaruh, Nyanyian, A.B. Simpson, Pelayanan, Relevansi, GKII.

\section{Pendahuluan}

\section{Latar Belakang Masalah}

Berbicara tentang musik maka tidak akan pernah ada habisnya. Karena musik mengandung unsur-unsur yang universal, yang mampu melintasi batasan usia, jenis kelamin, ras, agama dan bangsa. Pengertian musik sangat luas, dalam musik terdapat irama, keindahan dan lirik. Musik merupakan bahagian yang tidak terpisahkan dari kehidupan manusia. Terutama masa sekarang, musik digunakan secara luas dalam berbagai suasana dan tujuan. ${ }^{1}$ Musik merupakan anugerah yang diberikan Tuhankepada manusia untuk memuji-Nya. Manusia diciptakan berdasarkan peta dan gambar Allah yang amat kreatif yang bisa menyanyi, tertawa, dan bersukaria.

Ketika Allah menciptakan alam semesta ini, Dia memasukkan unsur musik dalam setiap bahagian dari ciptaan-Nya. ${ }^{2}$ Namun, dalam perkembangannya musik disalah artikan dan disalah gunakan oleh manusia. Ada beberapa musisi yang menggunakan musik untuk sesuatu yang buruk. Eminem, sang Rapper berkulit putih, sering menggunakan kata-kata kotor dalam setiap lirik-lirik lagunya. Dalam setiap penampilan, Britney Spears sering berpakaian seksi sehingga membuat parah pria yang melihatnya terpicu untuk berfantasi cabul. $^{3}$

\footnotetext{
${ }^{1}$ Jane Struat Smith dan Betty Carlson, Karunia Musik Para Komponis Besar Dan Pengaruh Mereka (Surabaya: Momentum,2013),2.

${ }^{2}$ Mike dan Viv Hibbert, Pelayanan Musik (Yogyakarta: Yayasan ANDI, 1988),1.

${ }^{3}$ Winnardo Saragih, Misi Musik Menyembah atau Menghujat Allah?(Yogyakarta: ANDI, 2008), 11.
} 
Bernyanyi dan bersoraklah bagi Tuhan dengan segenap hati (Efesus 5:18-19). Kitab Mazmur menjadi tulang punggung musik rohani. Kitab mazmur telah menjadi pusat ibadah, seiring dengan letak kitab Mazmur yang berada dibagian tengah Alkitab. Kitab ini merupakan suatu antologi puisi yang ditulis oleh berbagai penulis dalam satu periode zaman yang mencakup waktu sekitar seribu tahun, tetapi kemungkinan besar Daud menulis lebih dari setengah dari 150 pasal Mazmur yang ada. ${ }^{4}$

Salah satu bentuk musik ialah Nyanyian. Nyanyian merupakan suatu karya yang dihasilkan oleh manusia. Menurut Kamus Besar Bahasa Indonesia, nyanyian adalah komponen musik pendek yang terdiri atas lirik dan lagu; (nomina). Di dalam nyanyian terdapat irama, melodi, ritme, tempo, syair. ${ }^{5}$ Dalam nyanyian setiap kata-kata mempunyai arti dan makna tersendiri. Dari sisi rohani nyanyian merupakan ungkapan hati seseorang yang dituangkan dalam bentuk syair dan melodi sehingga membentuk sebuah nyanyian yang indah.

Dalam pembuatan syairnya, orang dapat menceritakan pengalaman pribadinya tentang perjumpaan dengan Yesus, bagaimana Yesus mengubah hidupnya, Yesus memberikan pengampunan, Yesus Juruselamat dan masih banyak lagi pengalamanpengalaman yang menginspirasi seseorang untuk membuat sebuah karya yang indah dan menjadi sebuah nyanyian yang memberkati semua orang yang mendengarkannya.

Ulangan 31:19 menyatakan, "Oleh sebab itu tuliskanlah nyanyian ini dan ajarkanlah kepada orang Israel, letakkanlah di dalam mulut mereka, supaya nyanyian ini menjadi saksi bagi-Ku terhadap orang Israel." Dengan demikian kita dapat menyimpulkan bahwa nyanyian itu bukan hanya dinyanyikan saja tetapi diajarkan terus menerus kepada semua orang dan menjadikannya sebagai gaya hidup. Dengan nyanyian kita dapat berkomunikasi dengan Allah, mengagungkan kebesaran Allah dan memuliakan Allah. Nyanyian sebagai sebuah tanda penyertaan Tuhan dalam perjalanan hidup kita. Menurut Jimmy Setiawan, pakar himnologi Erick Routley menyatakan bahwa:

Sebuah nyanyian dapat mempertobatkan orang, menguatkan iman, dan mengikat jemaat menjadi satu hati. Fungsi dan peranan nyanyian bukan hanya mengagungkan dan memuliakan Allah, tetapi dapat mempertobatkan orang. Nyanyian juga menguatkan hati jemaat yang mengalami masalah, pergumulan ataupun tantangan yang berat. Dari sisi sosial nyanyian dapat mempersatukan jemaat dalam perbedaanperbedaannya sehingga jemaat dapat bertumbuh secara dewasa dalam Tuhan dan berdampak bagi orang lain. ${ }^{6}$

Salah satu contoh lagu "It Is Well With My Soul” yang dituliskan oleh seorang kristen penganut Prebytarian bernama Horatio Gates Spafford. ${ }^{7}$ Lagu ini diciptakan ketika ia mengalami suatu musibah yang besar ketika anaknya berumur 4 tahun meninggal. Bukan hanya itu, pada saat istri dan keempat anak-anaknya berlayar ke Eropa, mereka mengalami kecelakaan maut, dimana kapal yang ditumpanginya ditabrak oleh sebuah kapal besi berbendera Inggris yang bernama Lochearn. Dalam musibah tersebut keempat

${ }^{4}$ Jane Struat Smith dan Betty Carlson, Karunia Musik Para Komponis Besar Dan Pengaruh Mereka (surabaya: Momentum,2013), 2.

${ }^{5}$ Kamus Besar Bahasa Indonesia (Jakarta: Balai Pustaka, 2001).

${ }^{6}$ Jimmy Setiawan“KuliahPenyembahanTuhan, NyanyianJemaatdanMusikIbadah"(Makassar, 6-8 Februari 2013), 2-3.

${ }^{7}$ Yusak I Suryana, Story Behind The Song Hymne and Kontemporer(Kisah Di balik Lagu) (Jakarta YIS PRODUCTION,2010),81. 
anaknya mengalami kematian dan hanya istrinya dan beberapa orang yang selamat. Dalam keadaan seperti itu ia menuliskan syair "When peace like a river attendeth my way, when sorrows like sea-bellows roll, Whatever my lot. Thou has taught me to say, it is well, it is with my soul."8

Sama halnya dalampelayanan A.B. Simpson. Ia merupakan seorang pengkhotbah dan pencipta lagu hymn yang terkenal. Lagu yang diciptakannya merupakan pengalaman pribadinya bersama Tuhan. Melalui nyanyiannya banyak jiwa dimenangkan dilepaskan dari ikatan dosa, dan menerima Yesus sebagai Juruselamat. Nyanyian membantu A.B Simpson untuk menyampaikan firman Tuhan yang akan disampaikan kepada orang-orang yang belum mengenal Tuhan. Dalam perjalanan pelayanan A.B. Simpson, banyak nyanyian dan karya yang ia ciptakan.

Dalam buku pelayanan dan karyanya ia menulis salah satu contoh lagu yang diciptakannya NKI 106 “Dapat Tuhan Yesus Dapat semuanya”' Nyanyian ini diciptakan ketika ia mengalami suatu masalah tentang pengudusan, ia beranggapan bahwa pengudusan diperoleh dari usaha sendiri. Ia mengejar pengudusan itu setiap hari. "Pengudusan itu pun hilang karena saya tidak berpegang pada Yesus Kristus." ${ }^{9}$ Namun, pada akhirnya ia menyadari bahwa pengudusan berasal dari Allah, Allah sendirilah yang berkarya atas hidupnya. Pengudusan bukan usaha manusia tetapi kasih karunia Allah yang dicurahkan atas manusia. Sehingga dengan pengalaman itu, ia menciptakan lagu ini sebagai ungkapan isi hati dan pengalaman pribadinya bersama-sama dengan Yesus.

Ketika Gereja Kemah Injil mengetahui dengan makna dan tujuan dari setiap lagu yang diciptakan maka nyanyian hymn ini akan dipertahankan. Namun, pada masa sekarang ini hal yang ditemui dalam Nyanyian Gereja Kemah Injil bukanlah Nyanyian Kemenangan Iman melainkan nyanyian kontemporer. Nyanyian kontemporer menjadi suatu nyanyian yang utama dalam kalangan gereja saat ini. Karena bagi gereja nyanyian kontemporer inilah yang dapat menarik dan membuat para kaum awam bahkan muda-mudi saat ini untuk datang beribadah.

Menurut pandangan penulis, Gereja Kemah Injil Indonesia cenderung mulai mengesampingkan Nyanyian Kemenangan Iman. Padahal dalam Nyanyian Kemenangan Iman, begitu banyak nasehat, ajakan, bahkan syair yang dapat merubah kehidupan seseorang.

\section{Pokok Masalah}

Melihat latarbelakang diatas, maka yang menjadi pokok masalah adalah

Pertama, Bagaimana pengaruh nyanyian karya Albert Benjamin Simpson dalam pelayanannya?

Kedua, Bagaimana Nyanyian Albert Benjamin Simpson dapat digunakan atau dipertahankan dalam ibadah Gereja Kemah Injil Indonesia?

\section{Tujuan Penelitian}

Adapun tujuan penulisan skripsi yang hendak dicapai oleh penulis yaitu :

Pertama, untuk mengetahui seberapa besar pengaruh nyanyian karya A. B. Simpson dalam pelayanannya.

Kedua, untuk memahami relevansi nyanyian A. B. Simpson bagi Gereja Kemah Injil Indonesia.

\footnotetext{
${ }^{8}$ Suryana, 83 .

${ }^{9}$ Albert Benjamin Simpson, Pelayanandan Karyanya (Bandung: Yayasankalamhidup, 2011), 88.
} 


\section{Manfaat Penelitian}

Adapun manfaat penulisan skripsi ini adalah sebagai berikut :

Pertama, berbagi pengetahuan yang jelas tentang pengaruh nyanyian karya A. B. Simpson dalam pelayanannya.

Kedua, berbagi pengetahuan yang jelas tentang relevansi nyanyian A. B. Simpson bagi Gereja Kemah Injil Indonesia.

Ketiga, untuk memenuhi salah satu syarat untuk menyelesaikan program studi strata satu (SI) di Sekolah Tinggi Theologia Jaffray Makassar.

\section{Metode Penelitian}

Peulis menggunakan metode kualitatif. Penulis tidak menggunakan data statistika. ${ }^{10}$ Selain itu, penulis juga menggunakan literatur- literature untuk membahas skripsi ini.

\section{Batasan Penelitian}

Dalam penulisan skripsi ini penulis hanya membahas sebatas pengaruh nyanyian karya A. B. Simpson dalam pelayanannya dan relevansinya bagi Gereja Kemah Injil Indonesia.

\section{Kepustakaan}

Kamus Besar Bahasa Indonesia. Jakarta: Balai Pustaka, 2001.

Mike dan Viv Hibbert. Pelayanan Musik. Yogyakarta: Yayasan ANDI, 1988.

Saragih, Winnardo. Misi Musik Menyembah atau Menghujat Allah? Yogyakarta: ANDI, 2008.

Siahaan, Rohani. "Memuji Dengan Nyanyian Dalam Ibadah Jemaat.” Jurnal Jaffray 5, no. 1 (2007). http://dx.doi.org/10.25278/jj71.v5i1.122

Siahaan, Rohani." Analisis Pengaruh Nyanyian Jemaat Terhadap Kualitas Ibadah Gereja Protestan di Indonesia bagian Barat (GPIB) Jemaat Bukit Zaitun Makassar.” Jurnal Jaffray 11, no. 2 (2013). http://dx.doi.org/10.25278/jij1.v11i2.82

Simpson, Albert Benjamin. Pelayanan Dan Karyanya. Bandung: Yayasan Kalam Hidup, 2011.

Smith, Jane Struat dan Betty Carlson. Karunia Musik Para Komponis Besar Dan Pengaruh Mereka. Surabaya: Momentum, 2013.

Suryana, Yusak I. Story Behind The Song Hymne and Kontemporer (Kisah Di balik Lagu). Jakarta: YIS PRODUCTION, 2010.

Wijaya, Hengki. Analisis Data Kualitatif: Ilmu Pendidikan Teologi. Makassar: Sekolah Tinggi Theologia Jaffray, 2018.

\footnotetext{
${ }^{10}$ Hengki Wijaya, Analisis Data Kualitatif: Ilmu Pendidikan Teologi (Makassar: Sekolah Tinggi Theologia Jaffray, 2018), 2.
} 